\title{
Effect of Nonlinear Pedagogy on the Performance of the Short Backhand Serve of Badminton
}

\author{
Seyed Kazem Mousavi ${ }^{1}$, Rasoul Yaali ${ }^{2}$ Abbas Bahram ${ }^{3}$, Ali Abbasi ${ }^{4}$ \\ 1. Seyed Kazem Mousavi, (M.A) Kharazmi University, Tehran, Iran \\ 2. Rasoul Yaali, (Ph.D) Kharazmi University, Tehran, Iran \\ 3. Abbas Bahram, (Ph.D) Kharazmi University, Tehran, Iran \\ 4. Ali Abbasi, (Ph.D) Kharazmi University, Tehran, Iran
}

\section{ARTICLE INFO \\ Received February 2017 \\ Accepted September 2017}

\section{KEYWORDS:}

Ecological Dynamics actions Nonlinear Pedagogy

Motor Learning

CITE:

Mousavi, Yaali, Bahram, Abbasi, Effect of Nonlinear Pedagogy on the Performance of the Short Backhand Serve of Badminton, Research in sport management \& motor behavior, 2020: 9(18):1-16

\section{ABSTRACT}

Motor learning or the acquisition of coordination is a process of searching for stable functional coordination patterns, into which a system can settle during a task or activity. Human as complex creatures can choose the best pattern based on conditions within different coordination patterns and also achieve goals of tasks. So the purpose of this study is to determination the effect of a Nonlinear Pedagogy approach for the effectiveness of the movement and acquisition of skills. Accordingly, in this study 14 participants (with the average 19.64 and SD 0.74) are taught the short backhand serve of badminton with using linear and nonlinear pedagogy approaches. Linear approach Based on traditional Viewpoint using the descriptive methods and repetive instructions. On the other hand, nonlinear Pedagogy Approach Based on the ecological dynamics theory using manipulation of task constraints especially task constraints including equipment and rules Planned and conducted. Performance accuracy were selected to analyze further selections and used analysis of covariance to measure the effect of the independent variable measured. The test significance level was considered $P<. / 05$. Despite the progress of both groups to the pre-test, no difference was observed between the two groups in accuracy scores ( $F=0.092$ and $p=0.767)$ and both were equal to achieve results of the task as an indicator of skill acquisition. Our findings indicate that nonlinear pedagogy approach, resulted from theory of ecological dynamics, consider the complexity of Acquisition the skill and inherent tendency of individuals with providing movement affordances. Also, this approach can be effective in the fulfilment of goal tasks. 


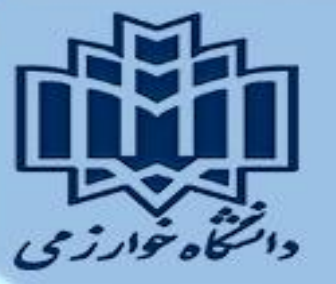

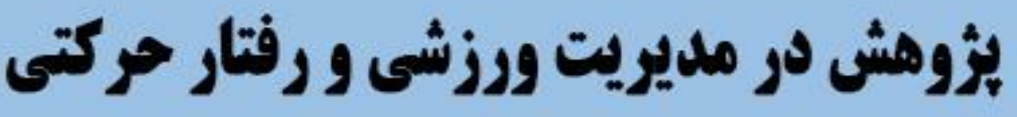

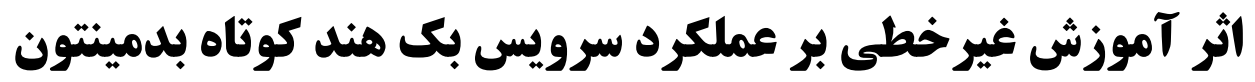

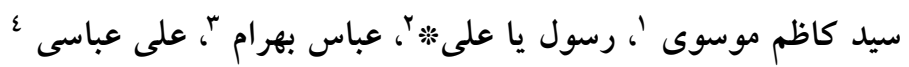

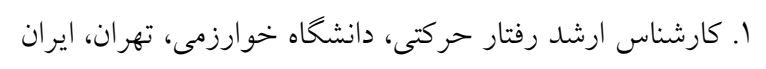

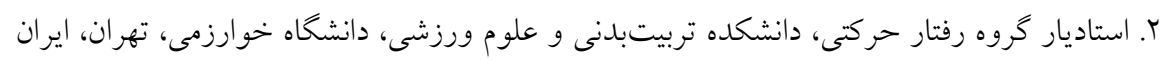

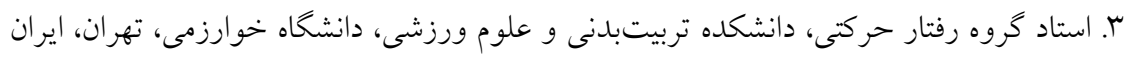

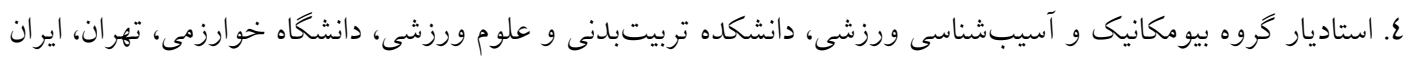
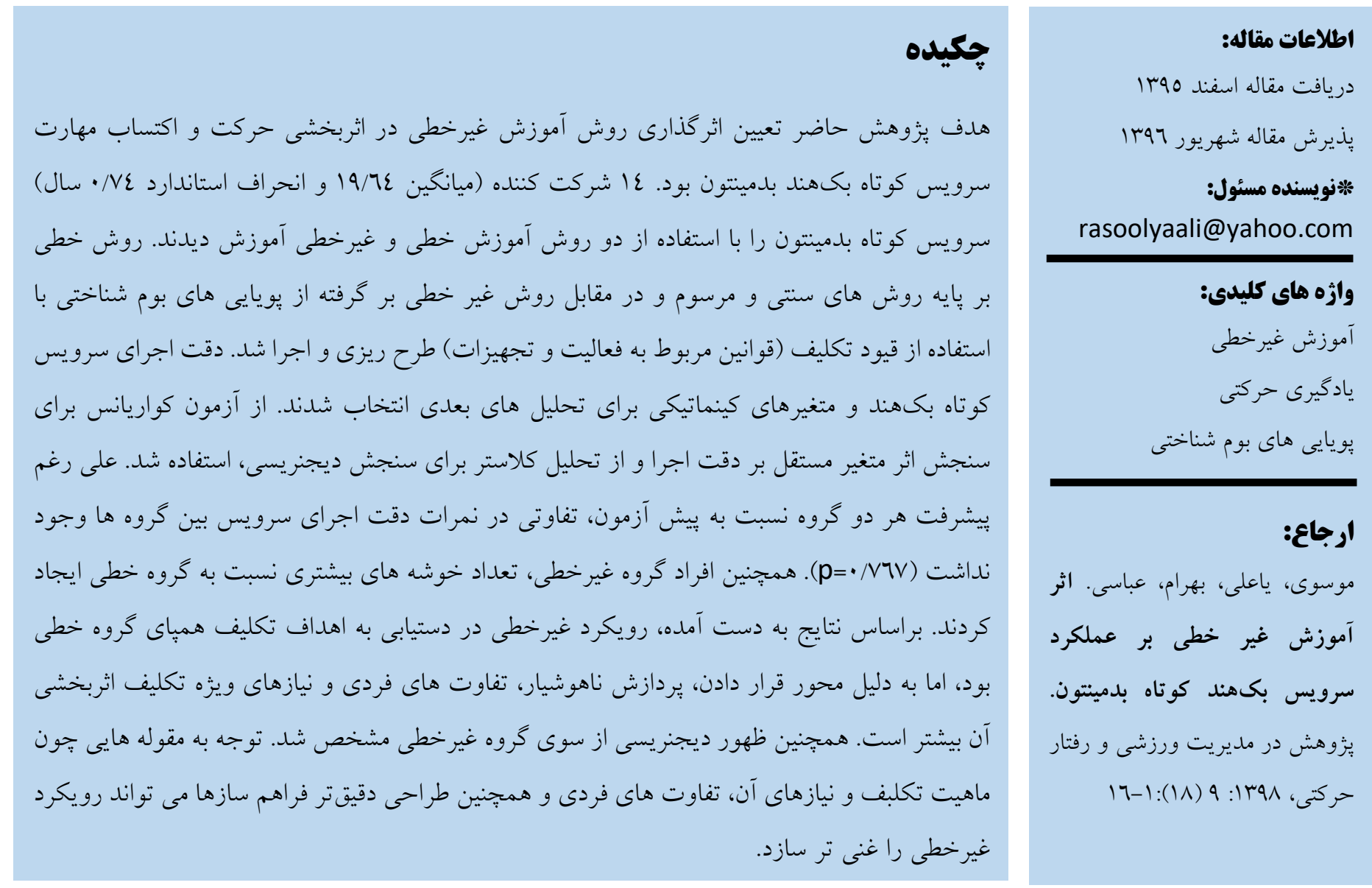

https://jrsm.khu.ac.ir/ 


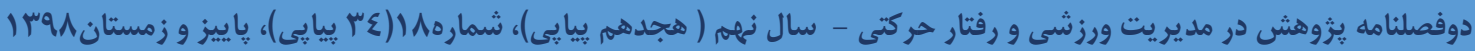

\section{مقدمه}

ياد گيرى حركتى يا اكتساب هماهنكى يكى فرآيند جستوجو براى رسيدن به الكوهاى هماهنگى كاركردى باثبات است كه يك سيستم مىتواند در طول يك كار يا فعاليت حلوفصل كند (1). آن كونه كه اين تعريف نشان مىدهد فر آيند اكتساب مهارت و ياد گيرى با رسيدن به يك الكوى هماهنكى خاتمه نمى يابد و ياد گيرنده با يك فرآيند جستوجو براى كسب مهارت مواجه است. نظريههاى سنتى اكتساب مهارت، بر مبناى استدلال منطقى، كلامى سازى، تقليد و درونى سازى دانش اخبارى و رويهاى بنانهاده شدهاند. بر اساس اين رويكرد از روشهاى آشكار يا تكرار دستورالعمل ها براى رسيدن به هدف تكليف بهره كرفته مىشود (Y). فرض زيربناى يك جنين رويكردى اين است كه يك الكوى حركتى ايدئال براى هر تكليف وجود دارد و نقش تمرين دهنده اين است كه يادكيرنده را براى خلق مجدد آن الكو كمى كند (ب). در اين رويكردها كه نوعاً به دنبال همسانى درحركت مىباشند (ع) اغلب تغييريذيرى بهعنوان نوفه يا خطاى اندازه خيرى قلمداد مىشود كه بايد حذف گردد (0)؛ اما نبايد فراموش كرد هر فردى كه درصدد يادكيرى مهارت حركتى باشد، موجودى يّيجيده با درجات آزادى فراوان و تجارب حركتى مختلف بهحساب مى آيد (7) كه داراى تمايلات ذاتى براى شكل دادن به الكوهاى هماهنكى است (0). بر همين اساس نظريه يويايى هاى بو ششناختى' بيشنهاد مى كند كه يادكيرند گان بايد بهعنوان دستخاههاى يو ياى غير خطى درى شوند كه شامل بخشهاى بى شمار هستند و بهصورت خودسازمان براى شكل گيرى الكوهاى پايدار با يكديخر تعامل مى كنند (0). در اين ديدگاه، هر فرد در پاسخ به تغييرات، رفتار متفاوتى از خود نشان مىدهد و وقتى در تعامل با قيود قرار مى گيرد به گونهاى متفاوت ياسخ مىدهد (V). به نظر مىرسد انسانها بهعنوان موجودات بييجيده مى توانند از ميان الكوهاى هماهنكى مختلف بهترين الكو را بر اساس شرايط انتخاب كنند و در ضمن آن به اهداف تكليف دست يابند. لذا توان افراد براى انتخاب راهحل حركتى و بهتبع آن دستيابى به نتايج دلخواه نبايد ناديده كرفته شود. نبايد فراموش كرد كه وجود تعداد زياد درجات آزادى طبيعتاً تغييريذيرى و تطابق را درحركت انسان نتيجه مىدهد (^). در تكاليف هماهنگ كه شامل عناصر جند گانه با درجات آزادى مىباشند، افراد مى توانند ضمن رسيدن به نتايج تكليفى يكسان از تنوعى از تركيبهاى مختلف بخش هاى سيستم استفاده كنند (9). بدين ترتيب رويكرد آموزش غيرخطى، تغييريذيرى كاركردى (سازشى) را مدنظر قرار داده است. همجنين مايل است مجموعه متنوعترى از الكوهاى حركتى را توليد كند كه براى افراد بسيار مناسب است (•) (1). مفهوم تغييريذيرى تحت تأثير بسيارى از قيود عمل كننده روى سيستم قرار مى گيرد (0) و اجازه مى دهد از ميان گزينهاى مختلف، استراتزىها انتخاب شوند (11). اين تغييريذيرى در

\footnotetext{
${ }^{1}$ Ecological dynamics
}

https://jrsm.khu.ac.ir/ 


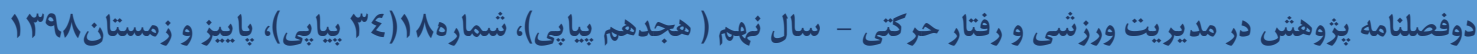

الكوهاى حركتى و رسيدن به راهحل حركتى، ديجنريسى نام دارد كه توانايى سيستم هاى بيجتيده عصبى - زيستى براى به دست آوردن راهحل هاى مختلف براى تكليفى با هدف يكسان به حساب مى آيد (1 آ).

رويكرد غيرخطى آموزش از دستكارى قيود تكليف مانند دستور العمل ها، قوانين مربوط به فعاليت و تجهيزات (به عنون مثال راكت، توتِ و اندازه زمين)، استفاده مى كند. در اين رويكرد تلاش مىشود با مهيا نمودن فراهم سازهاى عملكردى ادراى و عمل يكى شود. بدين ترتيب يادكيرنده را به كشف راهحل هاى حركتى مختلف تشويق مىكند كه براى آن ها مناسب ترين است (rا ). به طور قطع ادراك و تجارب هر فرد با فرد ديخر متفاوت است كه در اين رويكرد سعى مىشود افراد از طريق الكوهاى اختصاصى به نتايج تكليف دست يابند و تفاوت هاى فردى در يك جارجوب آموزشى مناسب در نظر كرفته شوند. استفاده از فرآيندهاى دستكارى قيود در طراحى جلسات يادگيرى مىتواند منجر به ظهور ياسخ هاى حركتى فردى به نسبت يويايى هاى درونى اجرا كننده گردد (ع ()). در اين ارتباط، برنشتاين (197V)، نشان داد، آهنگران

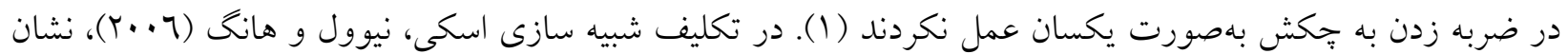
دادند كه شركت كنند گان مختلف قادر هستند كه از الكوهاى هماهنكى متفاوتى براى دستيابى به نتايج اجرايى يكسان استفاده كنند. زمانى كه روابط حركتى زانو مورد بررسى قرار كرفت، شركت كنند گان هر دو الكوى هم فاز و فاز مخالف را به طور موثر با مركز جرم و صفحه اسكى هماهنگ اجرا كردند. نتيجه كرفته شد كه على رغم سازماندهى مختلف مفاصل در مجموع عملكرد مشابه اى به دست آمد (10). به طور مشابه رين و همكاران ( • •(Y)، كينماتيك كل بدن را در شوت هوى بسكتبال مورد تجزيه و تحليل قرار دادند و تفاوت بين فردى زيادى در هماهنكى آرنج-شانه و زانو-ران در

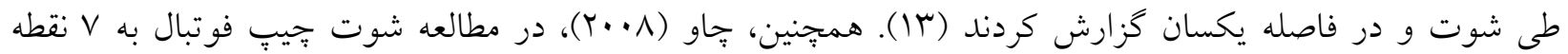
مختلف، نشان داد كه تفاوت هاى افراد در كسب هماهنكى و كنترل حركت مفصل حتى تحت شرايط قيدى يكسان هم

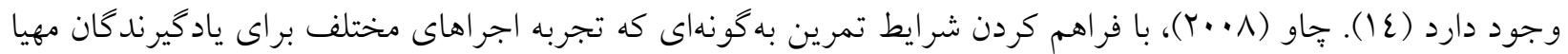
كردد، قابليت كشف و ايجاد الكوهاى متنوع را در طى اكتساب شوت جيتٍ فوتبال نشان داد. كومار و همكاران (ع (ب)، به بررسى اثر دستورالعملهاى قياسى در شناى قورباغه يرداخت. على رغم اينكه كيفيت هماهنكى بين اندامى در گروه قياسى بهبود يافت، نتايج حركت اين گروه نسبت به گروه كنترل كه سريع تر طى كردن مسافت بود، تفاوتى را نشان نداد (10). همجنين كومار و همكاران (10 (Y)، در تحقيقى با عنوان ديجنرسى عصبى زيستى در حمايت از ثبات، انعطاف

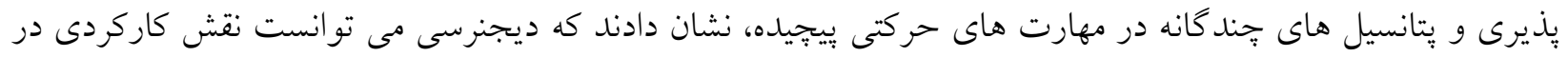
اطمينان از ثبات در عين انعطاف يذيرى در اكتساب مهارت حركتى، داشته باشد (19). علاوه بر آن، لى و همكاران (ع (ب)، با استفاده از فرآيند دستكارى قيود به آموزش مهارت فورهند تنيس به دو روش خطى و غيرخطى برداختند و نشان دادند 


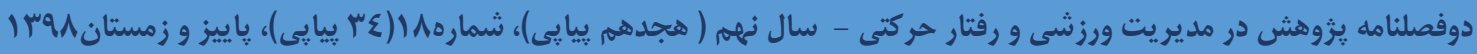

تغييريذيرى حركت الزاما مضر نيست و براى به دست آوردن يك مهارت جديد مورد نياز است، اخرجه، دو گروه در رسيدن به نتايج تكليف عملكرد يكسانى داشتند ( (Y).

نتايج تحقيقات نشان مىدهد به طور مشخص افراد از الكوهاى هماهنكى مختلفى براى رسيدن به اهداف تكليف بهره مى كيرند و اين مسئله در رويكردهاى سنتى آموزش مورد توجه قرار نخرفته است. اين در حالى است كه در رويكردهاى جديل، ديجنرسى را در سنجش هماهنكى در سسيستم هاى عصبى-زيستى بسيار مناسب مى دانند و يادگيرنده مىتواند براى كشف روابط اصلى و تعامل ميان قيود تشويق شود. از سويى شعار اصلى در رويكرد نوين آموزش، فراهم ساختن امكان ظهور اين الكوهاى هماهنگى و توجه به يويايى ياد گيرى و يادگيرنده است. به واقع تشويق ياد گيرنده براى اكتشاف با اين هدف انجام مى شود كه ضمن بهره كيرى از تمايلات افراد، به اهداف تكليف دست يافت. در اين زمينه يزوهش هاى كمى مداخلات آموزشى با رويكرد غيرخطى به انجام رسيده اند. اخرجهه تحقيق لى اثربخشى رويكرد آموزش غيرخطى و ظهور ديجنرسى را نشان داد، اما مشخص تر شدن اثر بخشى رويكرد آموزش غيرخطى در مقام مقايسه با رويكرد سنتى بهعنوان روشى موثر در به حساب آوردن تمايلات ذاتى و فرديت در اكتساب مهارت و رسيدن به اهداف تكليف، گره كشا خواهد بود. لذا يُزوهش حاضر در جهت تعيين اثربخشى روش آموزش غيرخطى بر اكتساب مهارت سرويس كوتاه بدمينتون و ظهور ديجنريسى، به انجام رسيده است. يزوهش ما دوفرضيه را مبناى قرار داده است. فرضيه اول اين بود كه ميان رويكرد آموزش خطى و غيرخطى تفاوت وجود دارد. فرضيه دوم اين بود كه رويكرد آموزش غيرخطى باعث ظهور ديجنريسى مى شود.

\section{روش شناسى بثوهش}

\section{روش تحقيق:}

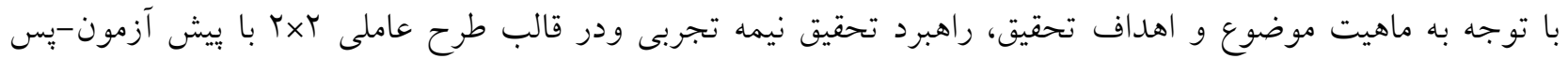
آزمون مى باشد. اين بززوهش با استفاده از روش بالينى اجرا كرديد. جامعه آمارى و نمونه تحقيق تعداد • r نفر از دانشجويان يسر كارشناسى تربيتبدنى، دانشگاه خوارزمى كه همخى آن ها راست دست بودند، براى اين تحقيق انتخاب شدند. تمامى شركت كنندكان مبتدى بوده و تجربه بسيار محدودى در استفاده از ورزش هاى راكتى داشتند. يس ازشروع روند كار ب نفر از گروه خطى و ب نفر از گروه غيرخطى، به دلايل شخصى از ادامه كار انصراف دادند و تنها

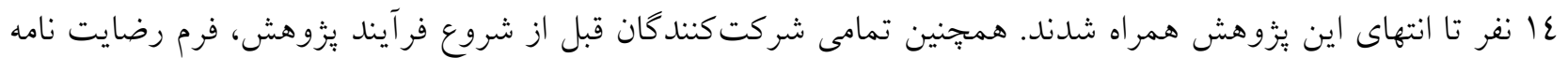




\section{ابزار جمع آورى دادهها}

در اين يزوهش به منظور سنجش دقت عملكرد، از آزمون سرويس بدمينتون استفاده شد. در اين آزمون زمين سمت راست بدميتون به V نقطه تقسيم شده است و به هر سرويس امتيازهايى از • تا V تعلق مى گيرد. هر تويى كه در منطقه خارج از

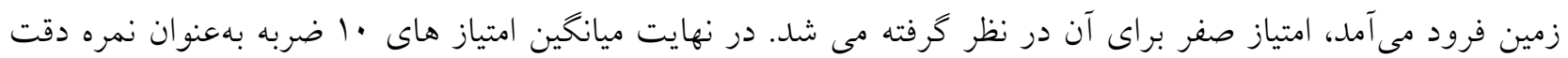

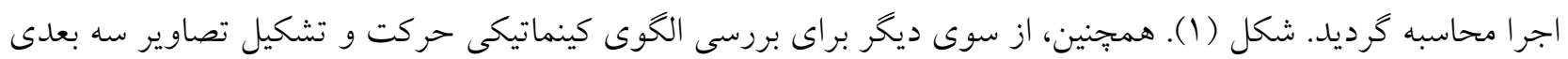
از تعدادى ماركر براى قرار كرفتن در نقاط از بيش تعيين شده استفاده گرديد. مدل دو بعدى الكوى كينماتيكى حركت با استفاده از ا دوربين كه در صفحه ساجيتال تعبيه شده بود، به دست آمد. كار تحليل اين الكو با استفاده از نرم افزار skill Spector

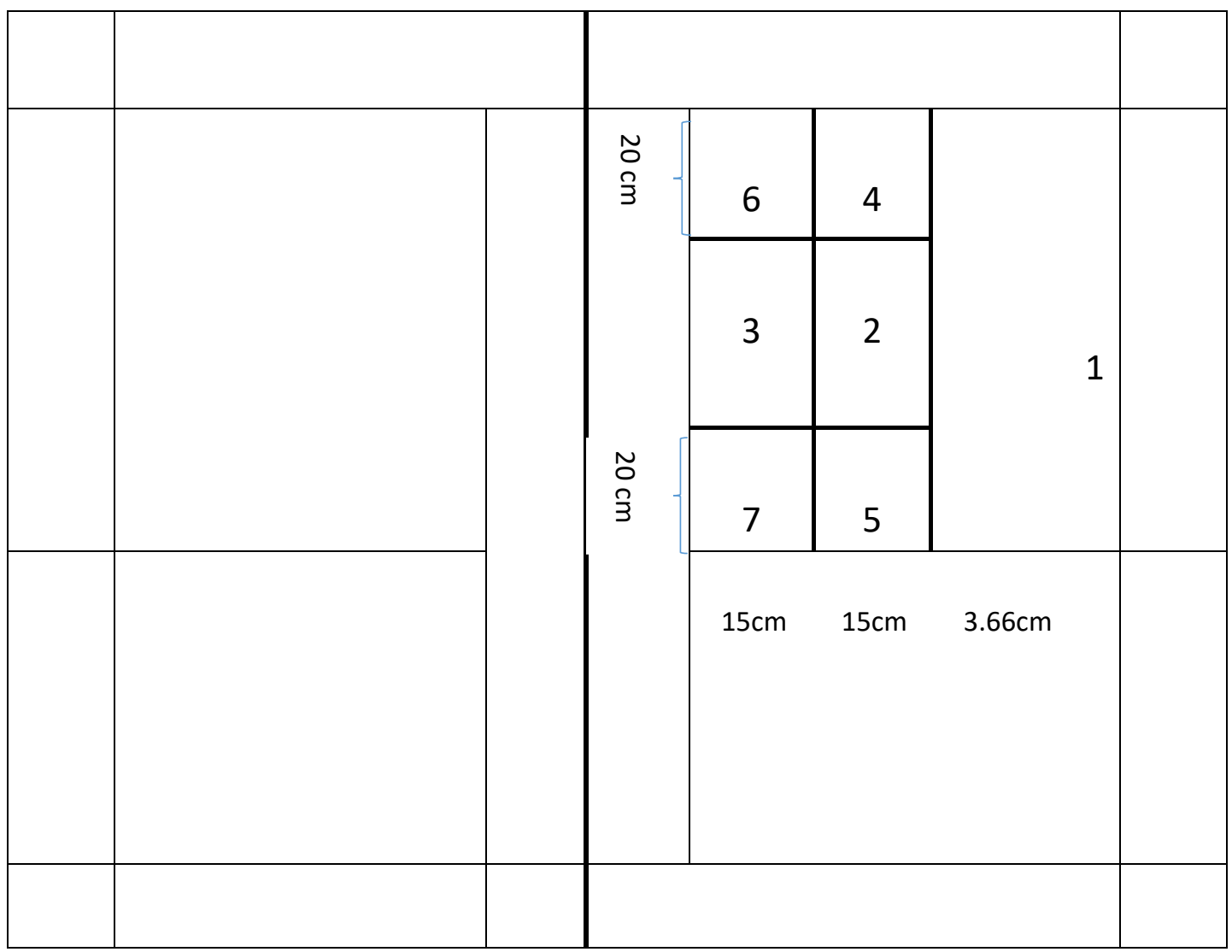

شكل 1. الكوى امتياز دهى سرويس بكهند بدمينتون 


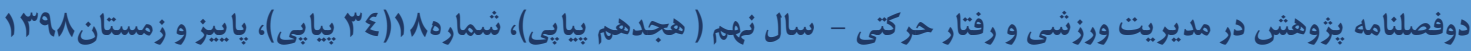

روش اجرايى

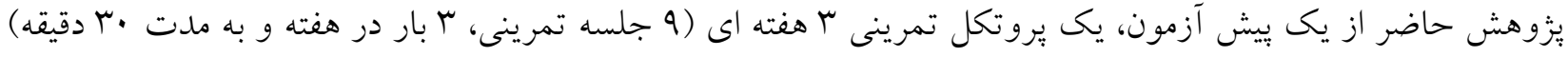

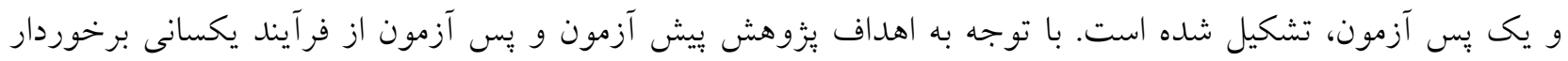
بودند. قبل از شروع فر آيند تحقيق افراد به طور تصادفى به دو گروه تمرينى آموزش خطى و غيرخطى تقسيم شدند. در طى

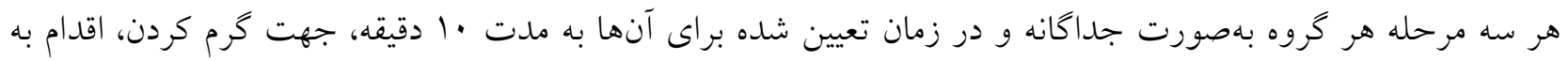
ضربه زدن به توبٍ كردند. شركت كنند گان، ضربات خود را از طرف راست زمين به سمت زمين بدمينتون خط كشى شده (بر اساس نقاط عطف در سرويس بكهند بدمينتون)، اجرا كردند. ابتدا شكل اجراى مهارت توسط يك فرد ماهر به ازمودنى ها نمايش داده شد. سبس قيود تكليف شامل قوانين مربوط به اين سرويس و خطاهاى آن به افراد گفته شد و براى اطمينان از يادگيرى كامل قوانين جند بار تكرار گرديد. در روز اول از هر گروه بهصورت جداكانه يك بيش آزمون كرفته شد و سبس طبق برنامه زمانبندى شده وارد دوره آموزشى (خطى و غيرخطى) شدند كه در ادامه بهصورت كامل به شرح آن

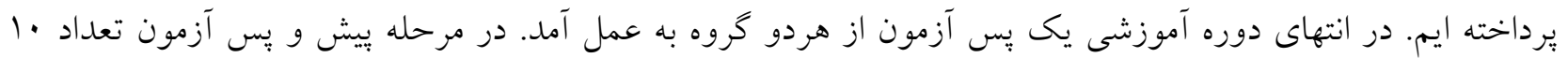
سرويس بكهند بدمينتون را به سمت زمين بدمينتون كه نقاط عطف با استفاده از خط كشى مشخص شده بود، اجرا كردند. در نهايت از آزمون سرويس براى محاسبه نمرات دقت استفاده شد، شكل ا. لازم به ذكر است كه در اين بزوهش ماركر كذارى بر روى نقاط آناتوميكى انجام شد كه شامل نقاطى بر روى زائده اخرمى، ايى كنديل خارجى، زائده استيلوئيد خارجى،

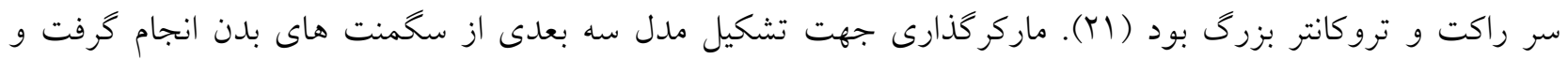
اطلاعات كينماتيكى حركت براى هر • ا ضربه توسط دوربين ديجيتال Casio، مدل Z200 ثبت گرديد.

\section{يروتكل تمرينى:}

اين دوره آموزشى از دو رويكرد خطى و غيرخطى تشكيل شده بود. هر دو گروه خطى و غيرخطى در هر جلسه تمرينى

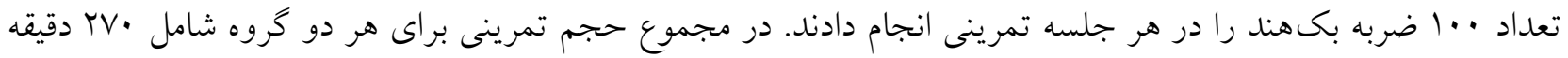
تمرين و .9 كوشش تمرينى بود. يروتكل تمرينى توسط تيم تحقيقاتى تدوين شده و از طرف متخصصين اكاه در زمينه رويكردهاى خطى و غير خطى تاييد شد كه از اهداف تحقيق آكاه نبودند. مداخلات خطى و غيرخطى بر بايه اين مفهوم كه

ياد گيرندكان مى تو انند بهعنوان سيستم هاى خطى و غيرخطى در نظر كرفته شوند، طراحى گرديد (†). براى دستكارى قيود تكليف در شرايط آموزش غيرخطى، در ابتدا شكل اجراى مهارت توسط يك فرد ماهر به ازمودنى ها نمايش داده شد. سبس قيود تكليف شامل قوانين مربوط به سرويس بكهند كو تاه بدمينتون و خطاهاى ان به افر اد كفته شد. قيود مربوط به تكليف با استفاده از روشهايى مانند، كوتاه كردن ارتفاع تور، افزايش ارتفاع تور، كاهش منطقه خطاى سرويس، افزايش منطقه خطاى سرويس، اجراى سرويس با راكت اسكواش، اجراى سرويس از ارتفاع بالاتر مثلا از روى

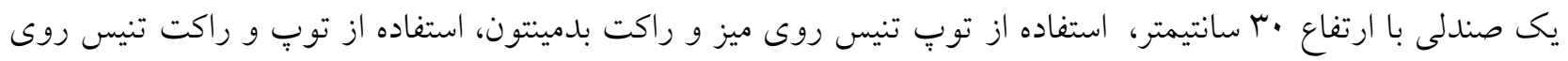




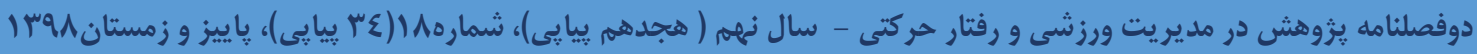

ميز، اجراى سرويس بدمينتون بهصورت مستقيم و نه مورب، اجراى سرويس از كناره هاى خط طولى خارجى زمين، دستكارى شد. اين دستكارى ها در هر جلسه تمرين براى همه افراد گروه آموزش غيرخطى انجام شده كه تغييريذيرى كاركردى را تشويق مى كند. هر كدام از افراد براى هر دستكارى • ا كوشش تمرينى انجام دادند. شركت كندكان در اين كروه دستور العمل هايى براساس ميزان ييشرفت در طى •r كوشش آخر در هر دور تمرينى دريافت كردند (بر اساس نقاط

عطف بازى هاى تورى اقتباس شده از هاير، (1991)) و در صورت تاييد به مرحله بعدى هدايت مى شدند (·r).

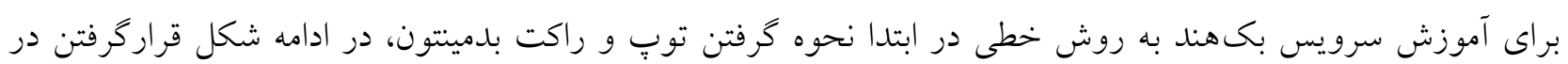
موقعيت سرويس، بهترين موقعيت براى زدن سرويس و نحوه وارد كردن ضربه، توضيح و نمايش داده شد. يس از جندين اجرا، در صورت نياز اجراى سرويس مجددا نمايش داده مى شد. همجنين تمرينات ويزه اين نوع سرويس، در برنامه تمرينى كُجانده شد تا ياد گيرنده، به الكوى ايده آل و بهينه دست بيدا كند. محور اصلى اين رويكرد استفاده از نشانه هاى دستورى

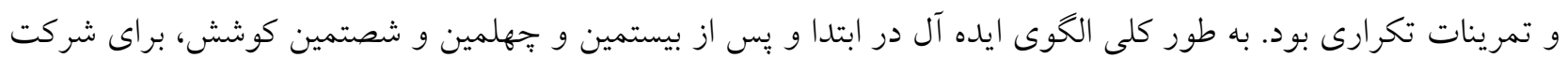
كنند گان به نمايش كذاشته و آن ها يك تمرين را به دنبال آن انجام دادند.

\section{روش تجزيه و تحليل آمارى}

از آزمون كواريانس براى تعيين اثر متغير مستقل روى هر دو گروه و از تحليل كلاستر براى سنجش ظهور ديجنريسى،

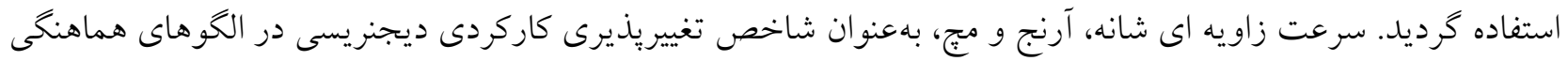
در زواياى اندام فوقانى ضربه جهت تحليل مورد استفاده قرار مى گيرد. تعداد بيشتر خوشه هاى حركت نشان دهنده وجود

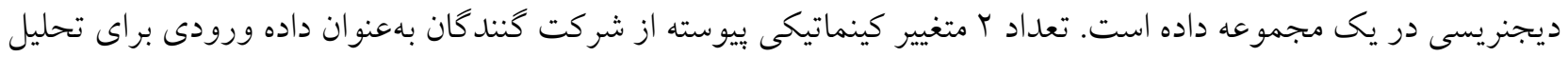

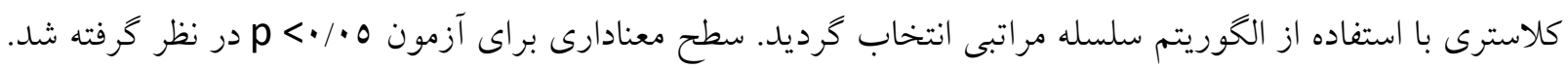

\section{نتايج تحقيق} فرضيه اول

با توجه به نتايج آزمون، مقدار F تعامل متغير كووريت (ييش آزمون گروه آموزش خطى) با متغير وابسته (يس آزمون گروه

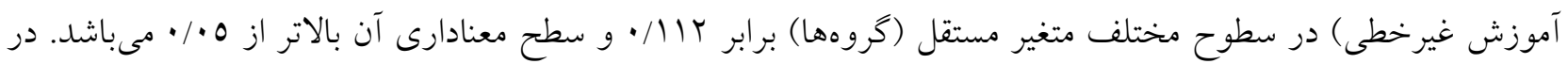
نتيجه شرط همخنى شيب خط رگرسيون بر قرار بود. 


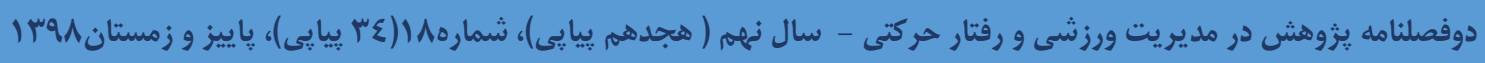

جدول ا. ميانگين و انحراف استاندارد نمرات دقت اجراى يس آزمون گروه ها

\begin{tabular}{|c|c|c|}
\hline انحر اف استاندارد & ميانگين & \\
\hline$\cdot / 999$ & 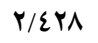 & خطى \\
\hline - & $r / r \cdot \cdot$ & غيرخطى \\
\hline
\end{tabular}

با استفاده از ازمون لون برابرى واريانس هاى خطاى نمره دقت اجرا به ازمون كذاشته شد و از آنجا كه سطح معنى دارى آماره F بزر گتر از ه • • است، بنابراين بايد گفت كه واريانس خطاى دو گروه با هم برابر بودهو تفاوتى بين آنها مشاهده

$$
\text { نمى شود (F=) (F= ( }
$$

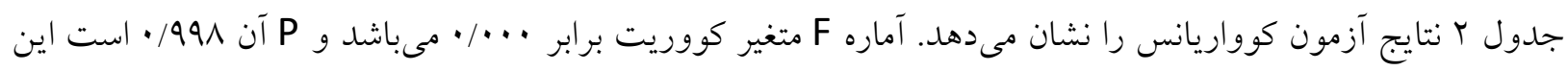
سطح معنادارى نشاندهنده آن است كه متغير كووريت همبستخى خطى با متغير وابسته (يس آزمون) ندارد يعنى متغير كووريت بر متغير وابسته تاثير گذار نيست. با خارج كردن تأثير متغير كووريت، تأثير متغير مستقل بر وابسته (يس آزمون)

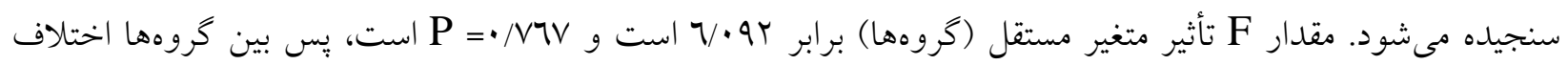
معنادارى وجود ندارد يعنى پس از خارج كردن تأثير بيش آزمون، اختلاف معنادارى بين ميانحين نمرات دو كروه در هي آزمون وجود ندارد.

$$
\text { جدول Y. نتايج مقايسه بين گروهى نمرات دقت اجرا }
$$

\begin{tabular}{|c|c|c|c|c|}
\hline P-Value & Fآماره F & مربع ميانخينها & Df & \\
\hline$\cdot / 90 \varepsilon$ & $\cdot / \cdot \varepsilon V$ & $\% \cdot r q$ & $r$ & مدل اصلاح شده \\
\hline.$/ 991$ & $\% \cdots$ & $1 .-7 \times 0 / 0.0$ & 1 & بيش آزمون (متغير كووريت) \\
\hline$\cdot /$ V V &.$/ .94$ &.$/ .0 \mathrm{~V}$ & 1 & گروهها (متغير مستقل) \\
\hline - & - &.$/ 711$ & 11 & خطا \\
\hline
\end{tabular}


جهت بررسى ظهور ديجنريسى از تحليل خوشه اى سلسله مراتبى بر مبناى ماتريس فاصله اقلديسى و مدل بين گروهى

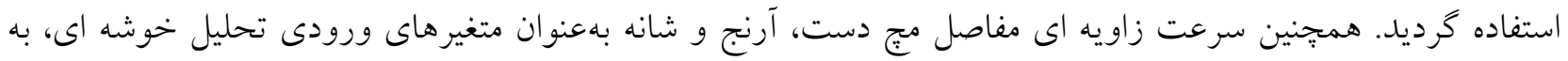

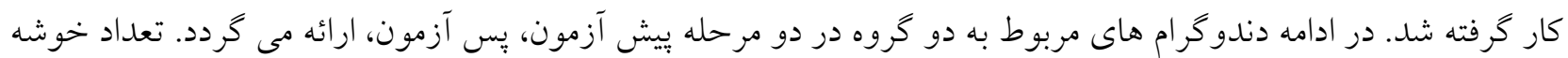
ها بيان كر وجود يا عدم ديجنريسى مى باشد.
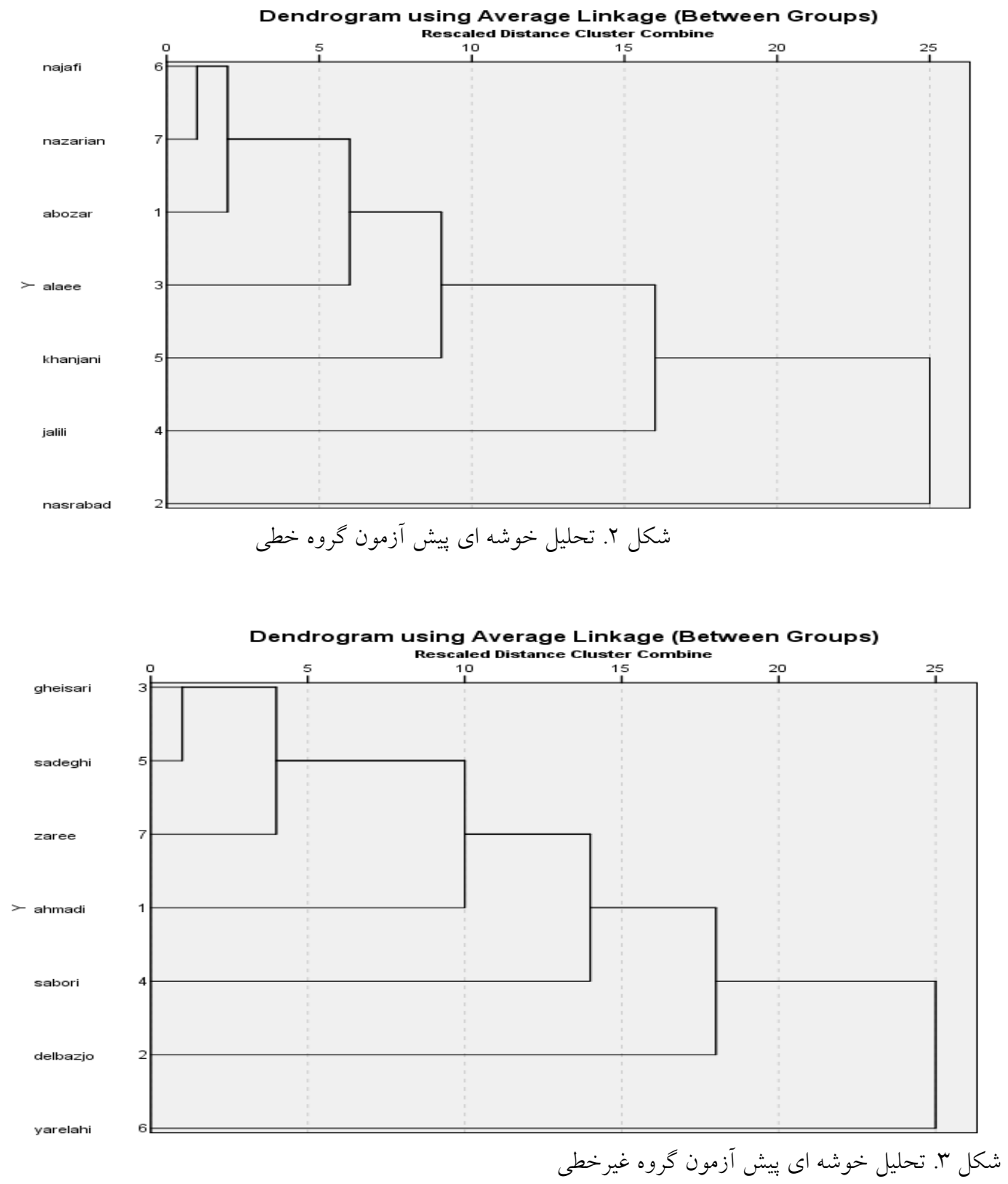

https://jrsm.khu.ac.ir/ 
با توجه به مبانى تحليل خوشه ایى سلسله مراتبى، تعداد خوشه بر اساس يك فاصله مناسب از ماتريس فاصله تعيين مى گردد و بر اساس دندو گرام ها، تعداد خوشه ها در مرحله بيش آزمون براى گروه خطى بّ بو براى گروه غيرخطى 0 خوشه

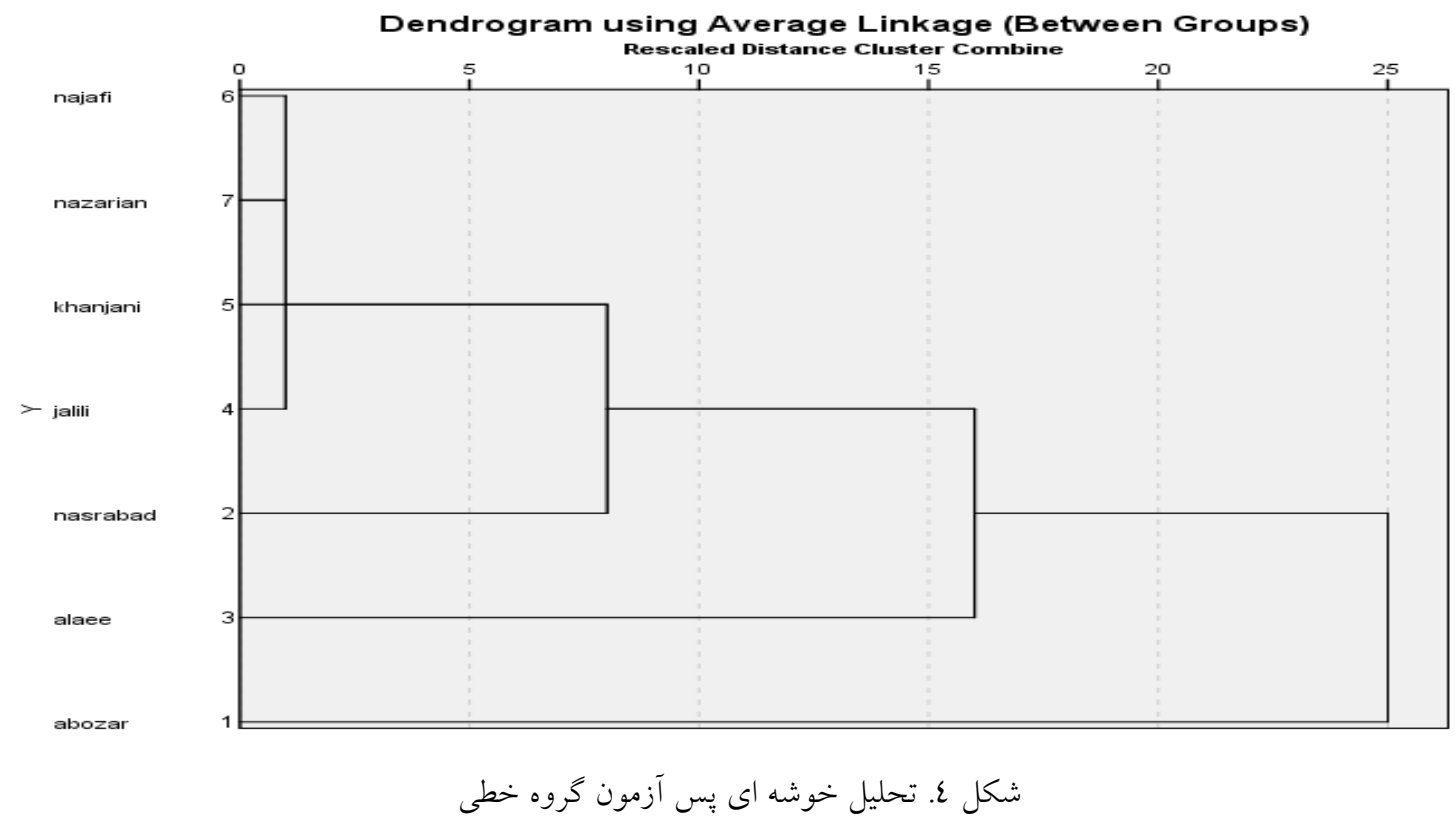

Dendrogram using Average Linkage (Between Groups)

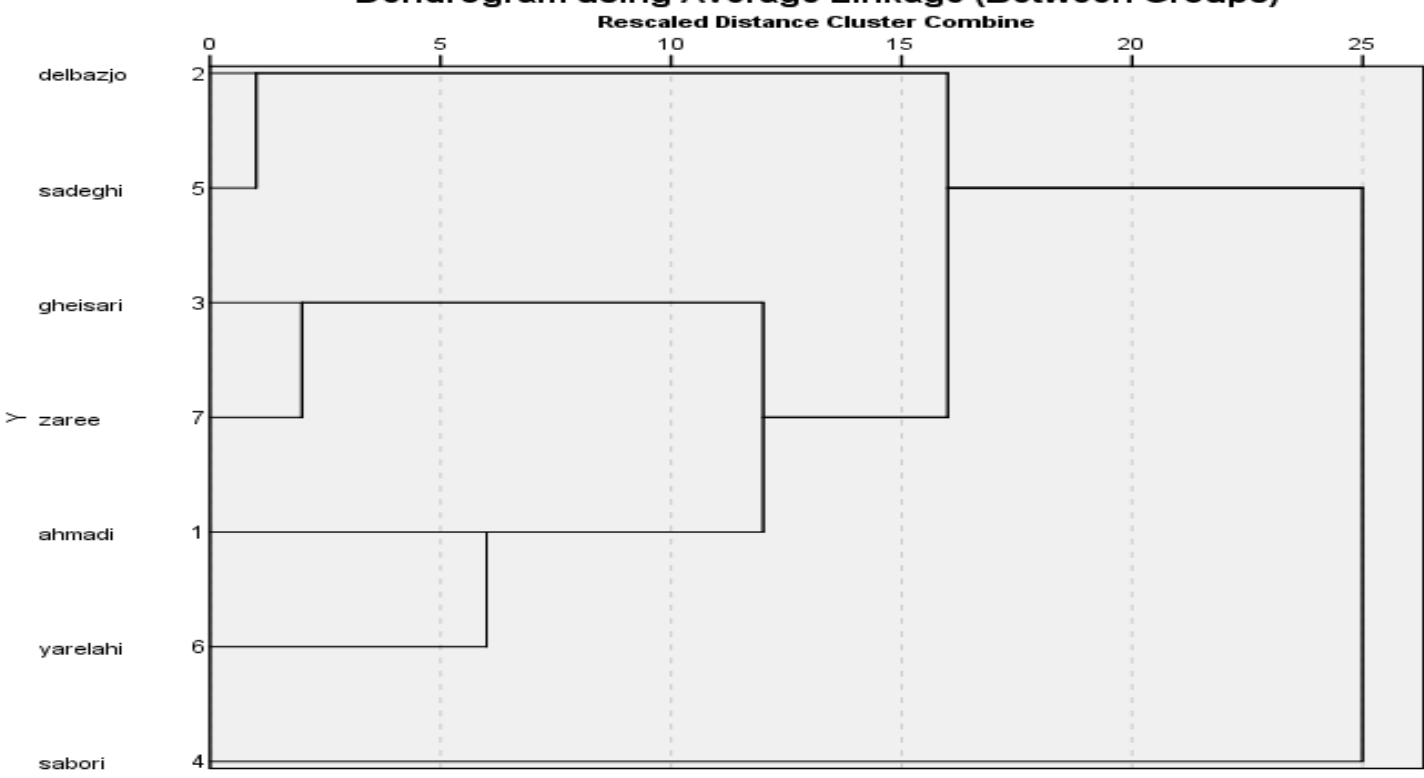

شكل 0. تحليل خوشه اى پِس آزمون كروه غيرخطى

https://jrsm.khu.ac.ir/ 


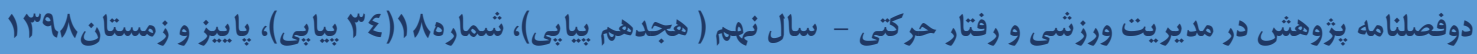

تصاوير مربوط به دنداكرام ها در مرحله يس آزمون حاكى از آن است كه تعداد خوشه ها در گروه خطى بّ و در گروه غيرخطى ع مى باشد.

\section{بحث و نتيجه تيرى}

يزّوهش حاضر با هدف مشخص نمودن اثر كذارى رويكرد آموزش غيرخطى در اكتساب مهارت سرويس كوتاه بدمينتون و ظهور ديجنريسى به انجام رسيد. تحقيقات كذشته ظهور الكوهاى حركتى گوناكون در ميان افراد مختلف طى اجراى مهارت و در ضمن آن رسيدن به نتايج تكليف را گزارش كردهاند؛ اما يزوهشى كه با به كار گيرى يك رويكرد آموزشى و مداخله تمرينى به دنبال مدنظر قرار دادن تمايلات ذاتى افراد براى شكل گيرى الكوهاى حركتى بهعنوان مولفه اى از ييجيديدى و رسيدن به نتايج تكليف باشد، كمتر به انجام رسيده است. در اين تحقيق فرض بر اين بود كه رويكرد غيرخطى روشى موثر در احتساب بيتيجيدگى انسان و دستيابى اهداف تكليف و ظهور ديجنريسى است. بر اساس نتايج يزوهش هر دو گروه آموزشى (خطى و غيرخطى) در يايان جلسات تمرينى ييشرفت از خود نشان دادند، اما هيج كدام از دو گروه برترى در نمرات دقت سرويس نسبت به ديخرى نداشتند. نتايج اين تحقيق نشان داد عليرغم ادعاى رويكردهاى غير خطى اين نوع از روش آموزش در دقت اجرا تاثيرى بيشتر از اموزش به روش سنتى ندارد، اما نمى توان اين مسئله را ناديده گرفت كه رويكرد غيرخطى توانسته افراد را در كسب نتايج هميا با كروه خطى، كمى كند. همان كونه كه تحقيقات كذشته نشان مىدهد، اجرا كنند كان قادر هستند كه از الكوهاى متفاوتى براى دستيابى به نتايج

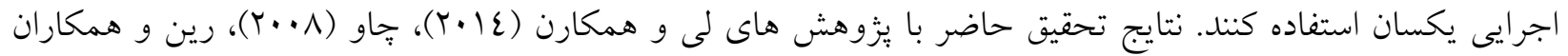

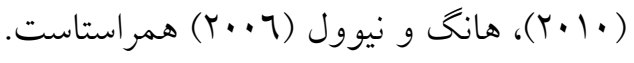

على رغم اينكه در مقاله كومار و همكاران (ع) (Y. تفاوتى بين گروه يادكيرى قياسى و كنترل در طول سيكل شناى قورباغه، بهعنوان نتيجه حركت مشاهده نشد، شايد بتوان كفت كه استفاده از الكوى قياسى با هدف ايجاد يك الكوى اختصاصى بوده است. از سوى ديخر، دستكارى تنها يك قيد در جهت دستيابى به نتايجى بهتر از سوى گروه قياسى بهعنوان مداخله آموزش غيرخطى، براى سطوح متفاوت افراد در اين بيزوهش كافى نباشد. اين دو مسئله از عمده تفاوت هايى است در باب مقايسه با يزوهش حاضر، به جشم مى خورد. علاوه بر آن به طور مشخص در بُزوهش لى (ع (Y)، با استفاده از رويكرد غيرخطى از طريق دستكارى قيود ضربه فورهند تنيس آموزش داده شد و على رغم اينكه الكوهايى از تغييريذيرى در اجراى شركت كنند گان به جشم مى خورد، توانستند همياى گروه خطى در رسيدن به نتايج تكليف موفق عمل كنند. 
آنجه مشخص است يادكيرى يك مهارت ورزشى يك فرآيند يِيجيده است كه تندين مولفه را در برمى گيرد (YT) و در يكى فرآيند يِيجيده اين مولفه ها يا يكديخر تعامل مى كنند. در اين ارتباط از جمله مولفه هاى تأثير كذار بر روند اكتساب و يادگيرى، ماهيت تكليف، تجارب و هوش حركتى افراد، ساختار بدنى و شرايط روانى است. در رويكرد سيستم هاى يوياى كنترل حركتى كه به دنبال ياسخ به وجود درجات آزدى نيز هست، هماهنكى حركت بهعنوان يك خصوصيت ظهور يافته خود تنظيم، تلقى مىشود (سب). در سيستم هاى حركت انسان، تعامل ميان اجرا كننده و محيط آن در شكل گيرى رفتارهاى خودتنظيم و خودسازمان سهيم است. ظهور خودسازمان راهحل هاى حركتى در يك فرآيند جستوجو گرايانه، از طريق تعامل ميان قيود اجراكننده، تكليف و محيط تسهيل مى گردد كه به واقع بهعنوان حد

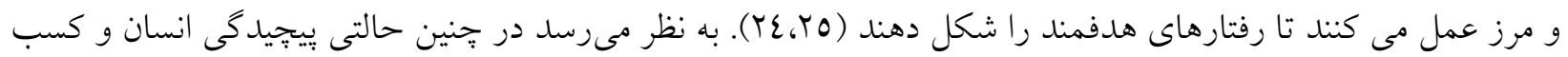
مهارت، بيشتر به حساب آورده مىشود. به طور قطع اگر تعداد راه هاى رسيدن به هدف يك دامنه را در بربخيرد، فرصت هاى حركتى براى خلق الكوهاى هماهنكى براى كستره وسيعى ترى از افراد فراهم خواهد شد نسبت به اينكه يكى مرز وجود داشته باشد كه به دنبال آن امكان رسيدن به نتايج بيشتر مىشود به ويزه زمانى كه ادراك مستقيم زمينه ساز اين اجراى حركت باشد. همجنين، نتايج تحليل كلاستر حاكى از آن بود گروه غيرخطى، در مرحله يس آزمون، تعداد خوشه هاى بيشترى را از خود نشان داد كه نشان از وجود ديجنريسى است. اين نتايج، با بزوهش لى و همكاران (ع (ب)، جاو (1) (Y) و كومار (Y) (Y)، همراستاست. نكته جالب توجه اين است كه گروه خطى تعداد ب خوشه در بيش آزمون را در مرحله يُ آزمون حفظ كردند و به عبارتى تعداد الكوهاى حركتى از يِيش آزمون تا بس آزمون تغييرى بيدا نكرد كه شايد كواه جارجوب بسته اى است كه رويكرد خطى براى يادگيرندگان به وجود مى آورد. در مقابل تعداد خوشه هاى گروه خطى در از ه به ع در طى بيش آزمون به يس آزمون تغيير كرد كه به نظر مىرسد رويكرد غيرخطى در خلق الكوهاى متنوع اكرجه در دامنه مشخص تر، مفيد بوده است. نكته مهم در اينجا اين است كه در تحقيق لى (عا.ب)، ظهور تعداد خوشه ها درهر دو مرحله آزمون، با تحقيق حاضر مشابه بود. نگاهى دقيقتر به كار كومار و همكاران (10)، (10)، نشان مىدهد كه گروهها در شرايط قيدى متفاوت توانسته بودند كه الكوهاى حركت را پارامتربندى كنند و به مشتقات مرتبه بالاترى دست ييدا كنند كه مى توان به قرار داشتن آن ها در مرحله كنترل از ياد كيرى، اشاره كرد. اين نتايج براى گروه خطى از سوى رويكردهاى سنتى قابل توجيج مى باشد، جرا كه همسانى در اجراى و بازآفرينى الخوى ايدهآل از اهداف اساسى در اين ديد گاه مى باشد كه نقش موثرى در رسيدن به اهداف تكليف دارد؛ اما در نقطه مقابل، در نگاه يويايى هاى بوم شناختى در طى فعاليت هاى هدفمند تعامل ميان قيود به طور مرتب برقرار است تا سيستم حركتى انسان را براى 


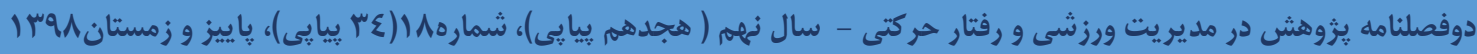

رسيدن به راهحل هاى حركتى مختلف به جالش درآورد و رفتارهاى هدفمند ويزه در اثر تعامل قيود غالب در يك نقطه زمانى مشخص ظاهر مى شوند (T0). بر اين اساس اكتساب مهارت بهعنوان توسعه رابطه كاركردى ميان اجر اكننده و محيط تعريف مىشود (YTrVV). به واقع مى توان كفت كه تغييريذيرى در دل اين ديدكاه قرار دارد و اين ويزگى تحت عنوان ديجنريسى ظهور بيدا مى كند كه توانيى عناصر به لحاظ ساختارى متفاوت براى اجراى كاركردى يكسان يا توليد محصولى برابر تعريف مىشود (Y (I)؛ بنابر اين، رويكرد غيرخطى، جارجوب مناسب جهت به حساب آوردن تفاوت هاى فردى فراهم ساخته، توانايى توليد الكوهاى كاركردى را در افراد تحت عنوان ديجنريسى از طريق شكل گيرى به موقع سينرزى ها به وجود آورده است كه مىتواند براى محيط يوياى يادكيرى بسيار مناسب باشد. از اين منظر رابطه ميان اجرا كننده و محيط مهم است و بر جفت شدن ميان اطلاعات و حركت در هماهنكى هاى الكوهاى حركت تاكيد مى كند كه اين مسئله حاكى از اهميت فراهم سازها و ادراك آنها مى باشد. نظريه يويايى هاى بوم شناختى هم اعتقاد دارد شايد رسيدن فرد به ادراى مستقيم بهترين راه براى برآمدن از بس بيتجيدگى و بويايى اكتساب مهارت از سوى افراد و دستيابى به بهترين اجرا باشد. براين اساس به نظر مىرسد كه على رغم اينكه روشهاى سنتى آموزش بر ظهور الكوى حركتى ايده آل تاكيد دارند، نتايج اين بزوهش كواه اين است كه رويكرد غيرخطى توانسته با تاكيد بر تغييريذيرى كاركردى، زمينه يويايى براى ادراك مستقيم فراهم كند و ياسخ مناسبى به درجات آزادى براى بهره گيرى در زمينه يوياى اجرا داده باشد. همجنين، به توسعه الكوهاى اختصاصى هماهنخ، كمك كند و در تحقق اهداف تكليف تأثير كذار باشد. علاوه بر اين طراحى دقيق فراهم سازها كه به طور عمده از طريق دستكارى قيود به وجود مى آيد، مىتواند نتايج بهترى را رغم زند و در مقام مقايسه با رويكرد خطى لي تاثيرى كذارى بيشترى در كسب الكوهاى هماهنكى مرتبط با يك مهارت به خصوص داشته باشد و بهتبع آن نتايج اجرايى بهترى داشته باشد.

\section{نتيجه كيرى}

يزوهش حاضر با بهره كيرى از رويكرد غيرخطى بدون نياز به تاكيد بر روى الكوى خاصى از حركت و شكل آن نتايج مشابه با كروه خطى را نشان داد، اما به باتوجه به اينكه تاكيد اصلى در رويكرد غيرخطى بر يردازش هاى ناهوشيار، تفاوت هاى فردى و شرايط منحصر به فرد هر تكليف مى باشد، شايد بتوان اين رويكرد را اثربخش تر خواند. به طور كلى تحقيق حاضر همراستا ساير تحقيقات در حوزه آموزش غيرخطى، اثربخشى اين رويكرد را نشان داد و باعث ظهور ديجنريسى در الحوهاى حركتى گرديد. باتوجه به اينكه ادراى مستقيم در دل اين رويكرد قرار داشت، لذا اين نتايج مىتواند بيانكر مفهوم يويايى ياد گيرى و تمايل براى جستوجو از سوى يادگيرند گان باشد. توجه به مقوله هايى جون ماهيت تكلبف و 


$$
\begin{aligned}
& \text { نيازهاى آن، تفاوت هاى فردى و همجنين طراحى دقيقتر فراهم سازها مىتواند رويكرد غيرخطى را غنى تر سازد. در اين } \\
& \text { صورت ضمن در نظر گرفتن بيقيجيدگى هاى كسب مهارت و تمايلات ذاتى افراد در تحقق اهداف و رسيدن به نتايج دلخواه } \\
& \text { تكليف موثر خواهد بود. } \\
& \text { منابع }
\end{aligned}
$$

1. Chow J.Y, David's K, button C, Renshaw I, (2016). Nonlinear pedagogy in skill acquisition. $1^{\text {st }}$ Ed Routledge.

2. Abernethy B, Maxwell JP, Masters RSW, et al. Attentional processes in skill learning and expert performance. (2007), Handbook of sport psychology, 3rd ed. Hoboken, p. 245-63.

3. Williams AM, Hodges NJ (2005) Practice, instruction and skill acquisition in soccer: Challenging tradition. Journal of Sports Sciences 23: 637-650.

4.Ranganathan, R, \& Newell, KM. (2013), Changing Up the Routine: Intervention-Induced Variability in Motor Learning, Exercise Sport Science Review, 41, pp. 64-70.

5. David's K, Button C, Bennett S, editors (2008) Dynamics of skill acquisition: a constraints-led approach. 1st ed. USA: Human kinetics.

6. MARK L. LATASH (2008), synergy, Oxford University Press, New York.

7. Chow JY, David's KW, Button C, Renshaw I, Shuttleworth R, Uehara LA (2009). Nonlinear pedagogy: implications for teaching games for understanding (TGfU). TGfU: Simply Good Pedagogy: Understanding a Complex Challenge. 1:131-43.

8. David's, K. Bennett, S. \& Newell, K.M. (Eds). (2006). Movement system variability. Cham-

Paign, IL: Human Kinetics.

9. Latash, M.L. J.P. Scholz, and G. Schöner (2002). Motor control strategies revealed in the structure of motor variability. Exerc. Sport Sci. Rev. 30:26 -31.

10. Lee MCY, Chow JY, Komar J, Tan CWK, Button C (2014) Nonlinear Pedagogy: An Effective Approach to Cater for Individual Differences in Learning a Sports Skill. PLoS ONE 9(8) journal. Pone.

11. Smith T.J, Henning R, Wade M.G, Fisher T, (2015) Variability in Human Performance. CRC Press is an imprint of Taylor \& Francis Group.

12. Edelman GM, Gally JA, (2001). Degeneracy and complexity in biological systems. Proceedings of the National Academy of Sciences. 98(24):13763-8.

13. Tan CWK, Chow JY, David's K (2012) 'How does TGfU work?' examining the relationship between learning design in TGfU and a nonlinear pedagogy. Physical education and sport pedagogy 17: 331-348.

14. Seifert L, Button C, Davids K, (2013). Key properties of expert movement systems in sport. Sports Medicine. 43(3):167-78.

15. Hong, S.L. \& Newell, K.M. (2006b). Practice effects on local and global dynamics of the ski-simulator task. Experimental Brain Research, 169(3), 350-360.

16. Rein, R. Button, C. David's, K. \& summers, J. (2010). Cluster analysis of movement patterns in multiarticular actions: A tutorial. Motor Control, 14(2), 211-239

17. Chow, J.Y. David's, K. Button, C. \& Koh, M. (2008). Coordination changes in a discrete multi-articular action as a function of practice. Acta Psychological, 127(1), 163-176.

18. Komar J, Chow J-Y, Chollet D, Seifert L (2014). Effect of analogy instructions with an internal focus on learning a complex motor skill. Journal of Applied Sport Psychology. 26(1):17-32.

19. Komar J, Chow J-Y, Chollet D, Seifert L, (2015). Neurobiological degeneracy: Supporting stability, flexibility and pluripotentiality in complex motor skill. Acta psychological. 154:26-35. 
20. Lee MCY, Chow JY, Komar J, Tan CWK, Button C (2014) Nonlinear Pedagogy: An Effective Approach to Cater for Individual Differences in Learning a Sports Skill. PLoS ONE 9(8) journal. Pone. 21. Rab G, Petuskey K, Bagley A, (2002). A method for determination of upper extremity kinematics. Gait \& posture. 15(2):113-9.

22. Thelen E, Smith LB, Karmiloff-Smith A, and Johnson MH (1994) a dynamic systems approach to the development of cognition and action: MIT Press.

23. Newell KM (1986). Constraints on the development of coordination. Motor development in children: Aspects of coordination and control. 34:341-60.

24. Chow JY, David's K, Button C, Renshaw I, Shuttleworth R, et al, editors (2009) Nonlinear Pedagogy: Implications for Teaching Games for Understanding. Ottawa, Canada: Physical Health Education Association.

25. Renshaw I (2010) a constraints-led perspective to understanding skill acquisition and game play: a basis for integration of motor learning theory and physical education praxis? Physical Education and Sport Pedagogy 15: 117-137.

26. Araújo D, Davids K (2011). Talent development: From possessing gifts to functional environmental interactions. Talent Development \& Excellence. 3(1):23-5.

27. Zelaznik HN (2014). The past and future of motor learning and control: what is the proper level of description and analysis? 